연구노트

\title{
Radical scavenging and a-glucosidase inhibitory effects of Mongolian Iris bungei extract
}

\author{
Yun Hee Jeong, Gyeong Han Jeong, Tae Hoon Kim* \\ Department of Food Science and Biotechnology, Daegu University, Gyeongsan 38453, Korea
}

\section{몽골산 Iris bungei 추출물의 자유 라디칼 소거 및 a-glucosidase 저해 활성}

\author{
정윤희 · 정경한 · 김태훈* \\ 대구대학교 식품공학과
}

\begin{abstract}
In a continuing screening of selected medicinal plants native to Mongolia, the antioxidant and a-glucosidase inhibitory activities of methanol extract of Iris bungei were investigated. After extraction with $80 \%$ of methanol, the methanol fraction was further extracted with $\boldsymbol{n}$-hexane, EtOAc and $\boldsymbol{n}$-BuOH in order to obtain four different solvent-soluble fractions, namely $n$-hexane-soluble, EtOAc-soluble, $n$-BuOH-soluble and $\mathrm{H}_{2} \mathrm{O}$ residue. The antioxidant properties were evaluated by radical scavenging assay using 1,1-diphenyl-2-picrylhydrazyl (DPPH) and 2,2'-azino-bis (3-ethylbenzothiazoline-6-sulphonic acid) $\left(\mathrm{ABTS}^{+}\right)$radicals. The anti-diabetic efficacy of $I$. bungei extract was investigated by a-glucosidase assay. All tested samples showed dose-dependent radical scavenging and a-glucosidase inhibitory activities. Among the tested extracts, the EtOAc-soluble fractions showed the greatest radical scavenging activity and a-glucosidase inhibitory properties among other solvent-soluble fractions. This result suggested that there was a significant relationship between the total phenolic content and biological efficacy. Thus, I. bungei extract might be considered as a new potential source of natural antioxidant and as a a-glucosidase inhibitory source. A more systematic investigation of this biomass sill be performed for further investigation of activity against antioxidative and anti-diabetic effects.
\end{abstract}

Key words : Mongolian Iris bungei, total phenolic contents, DPPH, ABTS $^{+}$, a-glucosidase

\section{서 론}

자외선, 흡연, 매연, 약물 및 방사선 등의 요인으로 인해 인체 내에서는 과도한 양의 superoxide $\left(\mathrm{O}^{2}\right)$, nitric oxide(NO), nitrogen dioxide $\left(\mathrm{NO}_{2}\right)$, hydroxyl $(\mathrm{OH})$, peroxynitrite $(\mathrm{ONOO})$ 등과 같은 활성산소종(reactive oxygen species, ROS)이 생 성되어 생체 내에서 산화를 유발시키며(1), 이로 인한 과도 한 산화적 스트레스는 세포 구성성분인 지질, 단백질, 당, DNA 등에 비 선택적, 비가역적 파괴를 촉진하게 된다. 산화

*Corresponding author. E-mail : skyey7@daegu.ac.kr Phone : 82-53-850-6533, Fax: 82-53-850-6539

Received 22 August 2017; Revised 22 September 2017; Accepted 25 September 2017.

Copyright (c) The Korean Society of Food Preservation. All rights reserved.
적 스트레스는 인체의 노화를 촉진시키며 이로 인해 암, 뇌질환, 심혈관계질환, 피부질환 등의 산화에 의한 각종 질병을 유발한다(2-5). 생체내에서 활성산소종이나 자유라 디칼을 제거하여 노화방지, 성인병 예방 등의 기능을 나타 내는 화학물질을 항산화물질이라고 하며, butylated hydroxy toluene(BHT) 및 butylated hydroxy anisol(BHA) 등의 합성 항산화제가 개발되어 광범위하게 사용되었으나 $(6,7)$, 이들 합성화학 항산화물질은 암 및 지질대사 불균형 등의 심각한 부작용이 보고되어 사용을 제한하고 있는 실정이다(8).

최근의 경제성장 및 생활수준의 향상으로 인해 서구화된 식습관의 변화가 가속화됨으로 만성 대사성 질환 중 하나인 당뇨병의 발생률이 급격하게 증가하고 있으며, 발병연령은 점차 낮아지고 있는 추세로 더많은 인구가 당뇨병으로 인해 생활에 제약을 받을 것으로 추정된다(9). 당뇨병은 크게 두 가지로 나뉘며 제 1 형은 췌장 베타세포의 병변에 따른 
인슐린 결핍으로 인한 인슐린 의존성, 제 2 형은 인슐린 저항 성으로 인한 인슐린 비의존성 당뇨로 정의된다 $(10,11)$. 지 속적인 산화적 스트레스는 췌장 베타세포의 손상과 인슐린 분비감소를 유발하여 항산화 물질은 인체의 당뇨병 개선에 밀접하게 관련되어 있는 것이 알려져 있다(12). 한편 a -glucosidase는 소장점막에 존재하는 당분해 효소로서 이를 저해하면 탄수화물의 소화를 방해하여 소장에서의 흡수가 지연되므로 식후 급격한 혈당상승을 억제하여 급격한 혈당 상승을 방지하는 역할을 한다(13). 대표적인 a-glucosidase 저해제로는 acarbose 및 voglibose가 잘 알려져 있으나 이들 을 장기 복용 할 경우 다양한 형태의 부작용 $(14,15)$ 을 유발 할 수 있어, 보다 안전하고 기능적으로도 우수한 효능을 나타내는 a-glucosidase 저해제의 탐색이 필요한 실정이다. 현재까지 천연물로 부터 a-glucosidase 저해제의 분리 및 동정에 관한 연구가 보고되어져 왔으며(16), 최근의 다양한 a-glucosidase 저해 활성 소재 개발을 위한 연구결과 중, 몽골 전통약용 식물인 Ferula mongolica의 추출물에 대량으 로 존재하는 sesquiterpenoid류는 항당뇨 활성 소재개발에 광범위하게 사용되어지고 있는 a-glucosidase에 대해 우수 한 저해활성(17)을 나타내는 것으로 확인되었으며, 몽골산 식물로부터 a-glucosidase 저해활성소재 개발연구에 대한 연구자들의 흥미를 유발하고 있다.

Iris bungei는 붓꽃과(Iridaceae)로 몽골 전 지역에서 흔히 자생하는 약용식물이고, 몽골의 전승의학에서 항균, 항암 및 항염증(18)등의 효능으로 사용해온 식물이다. 최근 연구 에서 I. bungei 씨앗으로 부터 마우스의 암세포에 대해서 우수한 세포독성을 나타내는 benzoquinone 유도체 화합물 이 분리 동정되었다(19). 또한 I. bungei 뿌리의 메탄올 추출 물로부터 peltogynoid류의 신규 화합물이 분리 및 동정되었 으나, 이들 분리된 화합물 이외의 생리활성에 대한 연구는 미미한 실정이다 $(20,21)$. 따라서 본 연구에서는 I. bungei 전초 추출물과 각종 유기용매를 이용한 각 분획물에 대하여 $\mathrm{DPPH}, \mathrm{ABTS}^{+}$라디칼 소거 및 a-glucosidase 저해활성을 평가하여 우수한 활성을 확인하였기에 그 결과를 보고하고 자 한다.

\section{재료 및 방법}

재 료

본 실험에 사용된 시료는 몽골 울란바토르에서 2015년 10 월에 채취 후 음건한 Iris bungei를 사용하였다. 표본시료 는 대구대학교의 식품공학과 천연물 화학실험실에 보관하 고 있다. 본 실험에서 사용된 gallic acid, 1,1-diphenyl-2picrylhydrazyl(DPPH), 2,2'-azinobis-3-ethylbenzothiazoline6-sulfonic acid($\left(\mathrm{ABTS}^{+}\right)$, Saccharomyces cerevisiae 유래의 a-glucosidase, (+)-catechin 및 acarbose은 Sigma-Aldrich
Chemical Co.(St. Louis, MO, USA)로부터 구입하여 사용하 였고, 그 외에 사용된 용매 및 시약은 모두 일급 이상의 등급을 사용하였다.

\section{추출물의 제조 및 분획}

건조된 I. bungei 전초 $2.0 \mathrm{~kg}$ 을 분쇄기로 잘게 마쇄한 후 $80 \%$ methyl alcohol(MeOH) $5.0 \mathrm{~L}$ 로 상온에서 침지추출 을 3 일간 3 회 반복하여 여과 한 후 농축하였다. 얻어진 $I$. bungei $80 \% \mathrm{MeOH}$ 추출물 $(750.1 \mathrm{~g})$ 을 물에 현탁하여 비극 성 용매인 $n$-hexane으로 먼저 분획한 후 수층을 다시 ethyl acetate(EtOAc)와 $n$-butyl alcohol $(n-\mathrm{BuOH})$ 을 이용하여 각 각 순차적으로 3 회 분획하였다. 각 용매추출 분획물을 감압 농축하여 건조 시킨 후 각각 $n$-hexane 가용 분획물(93.0 $\mathrm{g}), \mathrm{EtOAc}$ 가용 분획물(101.1 g), $n$-BuOH 가용 분획물(333.4 $\mathrm{g}), \mathrm{H}_{2} \mathrm{O}$ 가용 분획물 $(195.1 \mathrm{~g})$ 을 각각 얻었다(Fig. 1). $80 \%$ $\mathrm{MeOH}$ 추출물과 유기용매를 이용한 각 분획물을 대상으로 라디칼 소거활성 및 a-glucosidase 저해활성 평가를 수행하 였다.

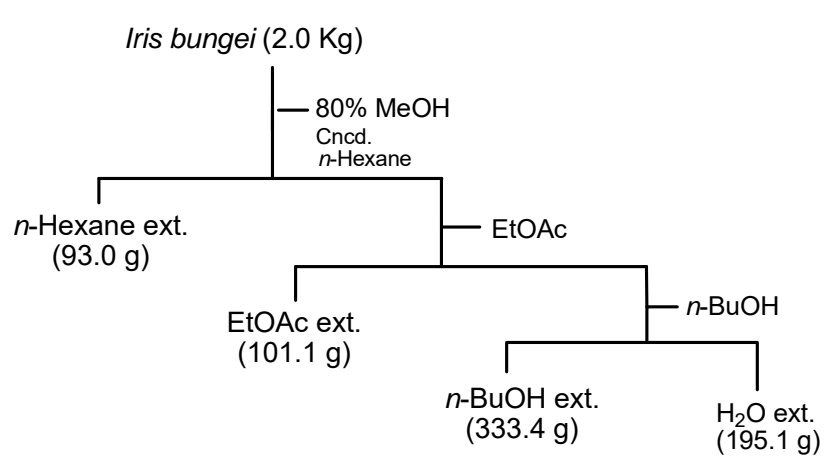

Fig. 1. Liquid-liquid partition of Mongolian Iris bungei.

\section{총 페놀성 화합물 함량 측정}

총 페놀성 화합물의 함량은 Folin-Denis 방법(22)에 따라 측정하였으며, 추출물 혹은 분획물을 $1.0 \mathrm{mg} / \mathrm{mL}$ 농도로 조제한 후, 시료 $50 \mu \mathrm{L}$ 와 Folin-Denis 시액 $50 \mu \mathrm{L}, 0.7 \mathrm{M}$ 탄산나트륨 포화용액 $50 \mu \mathrm{L}$ 를 차례로 넣은 다음 이것을 잘 혼합하여 실온에서 60 분 방치한 후 UV/VIS 분광광도계 로 $750 \mathrm{~nm}$ 에서 흡광도를 측정하였으며, 표준물질은 gallic acid를 이용하여 표준곡선을 작성하여 양을 환산하였다.

\section{$\mathrm{DPPH}$ 라디칼 소거능 측정}

몽골산 I. bungei의 $80 \% \mathrm{MeOH}$ 추출물 및 분획물의 전자 공여능은 Blois 방법(23)에 따라 측정하였다. 각 시료용액에 $120 \mu \mathrm{L}$ 에 $0.45 \mathrm{mM}$ 의 1,1-diphenyl-2-picrylhydrazyl(DPPH) 용액 $60 \mu \mathrm{L}$ 을 넣고 교반한 후 15 분간 방치한 다음 $517 \mathrm{~nm}$ 에 서 흡광도를 측정하였다. 전자공여능은 시료용액의 첨가군 과 무첨가군의 흡광도 차이를 백분율로 나타내었다. 


\section{$\mathrm{ABTS}^{+}$라디칼 소거능 측정}

몽골산 I. bungei의 $80 \% \mathrm{MeOH}$ 추출물 및 가용 분획물에 대하여 2,2'-azinobis-3-ethylbenzothiazoline-6-sulfonic acid $\left(\mathrm{ABTS}^{+}\right)$radical 소거능을 $\operatorname{Re}(24)$ 의 방법을 변형하여 다음 과 같이 측정하였다. $7 \mathrm{mM} \mathrm{ABTS}$ 와 $2.4 \mathrm{mM} \mathrm{K}_{2} \mathrm{O}_{8} \mathrm{~S}_{2}$ 동량을 혼합 후 실온, 암실에서 12시간 방치하여 라디칼의 생성을 유도한 후 $\mathrm{ABTS}^{+}$라디칼 용액을 희석하여 $734 \mathrm{~nm}$ 에서 흡광도 값이 0.7-0.8 정도가 되도록 희석한 후 사용하였다. 희석한 $\mathrm{ABTS}^{+}$라디칼 용액 $100 \mu \mathrm{L}$ 와 시료 $100 \mu \mathrm{L}$ 을 혼합하 여 실온에서 7 분간 반응시킨 후 $734 \mathrm{~nm}$ 에서 흡광도를 측정 하였다. 이때 positive control로는 (+)-catechin을 사용하였 으며 결과는 시료를 처리하지 않은 군에 대한 백분율로 나타내었다.

\section{a-Glucosidase 저해활성 측정}

a-Glucosidase 저해능은 $\operatorname{Eom}(25)$ 등이 행한 방법을 변형 하여 효소-기질반응을 이용한 분광학적 방법으로 측정하였 다. 즉, $1 \mathrm{U} / \mathrm{mL}$ a-glucosidase $90 \mu \mathrm{L}$ 에 시료 혹은 $0.1 \mathrm{M}$ sodium phosphate buffer(pH 6.8) $10 \mu \mathrm{L}$ 를 첨가하여 혼합한 후 $37^{\circ} \mathrm{C}$ 에서 15 분 동안 incubation 시켰다. 반응 후 기질인 $1 \mathrm{mM} p$-NPG $100 \mu \mathrm{L}$ 를 첨가한 후 5분간 반응시키고 405 $\mathrm{nm}$ 에서 ELISA reader를 이용하여 흡광도를 측정함으로써 기질로부터 유리되어 나오는 $p$-nitrophenol을 측정하였다. 양성대조군으로는 a-glucosidase 저해제로 알려진 acarbose 를 사용하였으며 a-glucosidase 저해활성은 시료용액의 첨 가군과 무첨가군의 흡광도 감소율로 나타내었다.

\section{통계처리}

실험결과는 SPSS package program(version 20.0, SPSS Inc., Chicago, IL, USA)을 이용하여 평균과 표준편차를 구 하였으며 실험군간 차이의 유의성은 one-way ANOVA에 의하여 $\mathrm{p}<0.05$ 수준에서 검증하였다.

\section{결과 및 고찰}

\section{총 페놀성 화합물 함량}

몽골산 I. bungei 추출물 및 각 분획물에 함유하고 있는 총 페놀성 화합물의 함량을 Table 1에 나타내었으며, $80 \%$ $\mathrm{MeOH}$ 추출물은 $1 \mathrm{~g}$ 당 $13.5 \pm 1.1 \mathrm{mg}$ 을 함유하는 것을 확인 하였으며 $\mathrm{EtOAc}$ 가용 분획물에서는 $31.0 \pm 2.2 \mathrm{mg}$ 의 가장 높은 총페놀함량을 나타내었다. 또한 n-hexane 및 $\mathrm{H}_{2} \mathrm{O}$ 가용 분획물에서는 각각 $1 \mathrm{~g}$ 당 $8.0 \pm 1.2 \mathrm{mg}, 10.5 \pm 1.4 \mathrm{mg}$ 을 총페 놀함량을 나타내었으며, $n-\mathrm{BuOH}$ 가용 분획물에서는 상대 적으로 가장 낮은 페놀 함유량 $3.9 \pm 0.5 \mathrm{mg} / \mathrm{g}$ 을 나타내는 것으로 확인되었다.

Table 1. Total phenolic contents of methanol extract and organic solvent fractions of Mongolian I. bungei

\begin{tabular}{cc}
\hline Samples & Total phenolic contents $(\mathrm{mg} \mathrm{GAE} / \mathrm{g})$ \\
\hline $80 \%$ MeOH ext. & $13.5 \pm 1.1^{\mathrm{bl})}$ \\
$n$-Hexane layer & $8.0 \pm 1.2^{\mathrm{d}}$ \\
EtOAc layer & $31.0 \pm 2.2^{\mathrm{a}}$ \\
$n$-BuOH layer & $3.9 \pm 0.5^{\mathrm{e}}$ \\
$\mathrm{H}_{2} \mathrm{O}$ layer & $10.5 \pm 1.4^{\mathrm{c}}$ \\
\hline
\end{tabular}

${ }^{1)}$ Data represent the mean \pm SD three replications. Mean separation within columns of respective seasons by Duncan's multiple range test at $\mathrm{p}=0.05$.

\section{$\mathrm{DPPH}$ 라디칼 소거활성}

Table 2에서 나타낸 것처럼 건조된 I. bungei 추출물 및 각 유기용매 분획에 대해서 $\mathrm{DPPH}$ 라디칼 소거활성은 $80 \%$ $\mathrm{MeOH}$ 추출물의 $\mathrm{IC}_{50}$ 값은 $173.2 \pm 16.8 \mathrm{\mu g} / \mathrm{mL}$ 의 라디칼 소 거활성을 나타내었으며, 특히 $\mathrm{EtOAc}$ 가용 분획물의 $\mathrm{IC}_{50}$ 값이 $148.7 \pm 11.6 \mathrm{\mu g} / \mathrm{mL}$ 의 가장 우수한 라디칼 소거활성을 나타내었다. 또한 n-hexane 및 $\mathrm{H}_{2} \mathrm{O}$ 가용 분획물에서 $\mathrm{IC}_{50}$ 값이 각각 $310.4 \pm 11.1 \mu \mathrm{g} / \mathrm{mL}$ 와 $217.6 \pm 12.6 \mu \mathrm{g} / \mathrm{mL}$ 의 EtOAc 가용 분획물 보다 상대적을 약한 라디칼 소거활성을 나타내 었다. $n-\mathrm{BuOH}$ 가용 분획물에서는 $\mathrm{IC}_{50}$ 값이 $500 \mu \mathrm{g} / \mathrm{mL}$ 이상으

Table 2. DPPH radical scavenging activity of $80 \%$ methanol extract of Mongolian $I$. bungei and its $n$-hexane, EtOAc-, $n$-BuOH-, and $\mathrm{H}_{2} \mathrm{O}$-soluble fractions

\begin{tabular}{|c|c|c|c|c|c|c|}
\hline \multirow{2}{*}{ Samples } & \multicolumn{5}{|c|}{ Inhibition (\%) } & \multirow{2}{*}{$\begin{array}{c}\mathrm{IC}_{50} \\
(\mu \mathrm{g} / \mathrm{mL})\end{array}$} \\
\hline & 500 & 250 & 125 & 62.5 & 31.3 & \\
\hline $80 \% \mathrm{MeOH}$ ext. & $72.0 \pm 1.2^{\mathrm{cl})}$ & $58.1 \pm 0.2^{\mathrm{c}}$ & $46.0 \pm 1.3^{\mathrm{c}}$ & $31.2 \pm 1.3^{\mathrm{c}}$ & $11.4 \pm 2.0^{\mathrm{bc}}$ & $173.2 \pm 16.8$ \\
\hline$n$-Hexane layer & $61.8 \pm 1.7^{\mathrm{e}}$ & $45.7 \pm 1.2^{\mathrm{e}}$ & $28.5 \pm 0.8^{\mathrm{e}}$ & $19.9 \pm 1.4^{d}$ & $10.4 \pm 1.8^{\mathrm{cd}}$ & $310.4 \pm 11.1$ \\
\hline EtOAc layer & $80.2 \pm 1.1^{\mathrm{b}}$ & $59.4 \pm 0.8^{\mathrm{b}}$ & $48.2 \pm 1.3^{\mathrm{b}}$ & $32.2 \pm 1.6^{b}$ & $14.3 \pm 0.2^{\mathrm{b}}$ & $148.7 \pm 11.6$ \\
\hline$n$-BuOH layer & $40.2 \pm 0.2^{\mathrm{f}}$ & $32.5 \pm 1.1^{\mathrm{f}}$ & $24.3 \pm 1.5^{\mathrm{f}}$ & $16.7 \pm 2.2^{\mathrm{e}}$ & $9.8 \pm 0.8^{d}$ & $>500$ \\
\hline $\mathrm{H}_{2} \mathrm{O}$ layer & $64.3 \pm 0.9^{\mathrm{d}}$ & $52.7 \pm 1.2^{\mathrm{d}}$ & $41.2 \pm 1.7^{\mathrm{d}}$ & $34.4 \pm 1.5^{\mathrm{b}}$ & $12.3 \pm 1.4^{b}$ & $217.6 \pm 12.6$ \\
\hline$(+)-$ Catechin $\left.^{2}\right)$ & $99.9 \pm 0.7^{\mathrm{a}}$ & $99.8 \pm 0.4^{\mathrm{a}}$ & $96.2 \pm 1.4^{\mathrm{a}}$ & $87.6 \pm 1.1^{\mathrm{a}}$ & $74.1 \pm 0.6^{\mathrm{a}}$ & $15.0 \pm 0.9$ \\
\hline
\end{tabular}

\footnotetext{
${ }^{1)}$ Scavenging activities are expressed as the mean $\pm \mathrm{SD}$ of triplicate experiments. Mean separation within columns of respective seasons by Duncan's multiple range test at $\mathrm{p}=0.05$.
} ${ }^{2)}(+)$-Catechin was used as a positive control. 
로 가장 낮은 라디칼 소거활성이었다. Table 2에서 나타낸 바와 같이 몽골산 I. bungei 전초 추출물의 $\mathrm{DPPH}$ 라디칼 소거활성은 Table 1 의 결과에서 확인한 것처럼 페놀성 화합 물의 함량이 상대적으로 높은 EtOAc 가용 분획물에서 우수 한 DPPH 라디칼 소거활성을 나타내었으며, 이들 결과는 $\mathrm{DPPH}$ 라디칼 소거활성은 페놀성 화합물의 함량과 밀접한 상관관계가 있다는 보고(26)와도 일치는 결과였다. 최근 연구에서 우수한 DPPH 라디칼 소거활성을 나타낸 몽골에 자생하는 약용 식물인 Dracocephalum foetidum의 지상부 추출물로부터 우수한 라디칼 소거 활성 성분이 분리되었다 (27). 또한 몽골 전통약용 식물인 바디풀(Leptopyrum fumarioides L.) 추출물에서도 우수한 DPPH 라디칼 소거활 성이 나타났으며 활성 성분이 분리 동정되었으며(28), 본 연구결과는 몽골산 자생식물 중 라디칼 소거 활성을 나타내 는 추가 자료로서 향후 물질 분리를 통한 활성성분의 구조 동정이 필요하다고 사료된다.

\section{$\mathrm{ABTS}^{+}$라디칼 소거활성}

항산화 활성평가에 광범위 하게 사용되는 $\mathrm{ABTS}^{+}$라디칼 을 활용한 활성 평가에서 Table 3에서 나타낸 것처럼 몽골 산 I. bungei의 $80 \% \mathrm{MeOH}$ 추출물 $\mathrm{IC}_{50}$ 값이 $50.9 \pm 1.9 \mathrm{\mu g} / \mathrm{mL}$
의 $\mathrm{ABTS}^{+}$라디칼 소거활성을 확인하였으며, 각 분획물중 에서도 특히 $\mathrm{EtOAc}$ 가용 분획물의 $\mathrm{IC}_{50}$ 값이 $27.8 \pm 0.9 \mu$ $\mathrm{g} / \mathrm{mL}$ 로 우수한 $\mathrm{ABTS}^{+}$라디칼 소거활성을 확인하였다. 이 결과는 양성대조군이 (+)-catechin( $\mathrm{IC}_{50}$ 값 $\left.=14.6 \pm 0.4 \mu \mathrm{g} / \mathrm{mL}\right)$ 과 유사한 라디칼 소거활성 이였다. 또한 $\mathrm{H}_{2} \mathrm{O}$ 가용 분획물 의 $\mathrm{IC}_{50}$ 값은 $45.2 \pm 3.0 \mathrm{\mu g} / \mathrm{mL}$ 의 라디칼 소거활성이 나타났 고, $n$-hexane 및 $n$ - $\mathrm{BuOH}$ 가용 분획물에서는 $\mathrm{IC}_{50}$ 값이 200 $\mu \mathrm{g} / \mathrm{mL}$ 이상으로 상대적으로 낮은 라디칼 소거활성을 나타 내었다. Table 1에서 나타난 것처럼 총 페놀 함량이 상대적 으로 높은 EtOAc 가용 분획물에서 $\mathrm{ABTS}^{+}$라디칼 소거활성 이 우수한 물질의 존재가 시사 되었으며, 향후 EtOAc 가용 분획물에 대하여 단일물질의 분리 동정 및 활성 물질의 탐색이 필요하다고 사료된다. 최근 연구에서 몽골에 흔히 자생하는 식물인 Agriophyllum squarrosum 의 씨앗 추출물 에서 우수한 $\mathrm{ABTS}^{+}$라디칼 소거활성을 나타냄이 확인되었 으며(29), 본 연구의 결과는 라디칼 소거능이 우수한 몽골산 식물의 추가적인 연구자료로 활용이 가능할것으로 사료된다.

\section{a-Glucosidase 저해활성}

I. bunge $i$ 를 $80 \% \mathrm{MeOH}$ 로 추출 후 유기용매를 이용하여 분획 후 가용 분획물에 대하여 a-glucosidase 저해 활성을

Table 3. $\mathrm{ABTS}^{+}$radical scavenging activity of $80 \%$ methanol extract of Mongolian $I$. bungei and its $n$-hexane-, EtOAc-, $n$-BuOH-, and $\mathrm{H}_{2} \mathrm{O}$-soluble fractions

\begin{tabular}{|c|c|c|c|c|c|c|}
\hline \multirow{2}{*}{ Samples } & \multicolumn{5}{|c|}{ Inhibition (\%) } & \multirow{2}{*}{$\begin{array}{c}\mathrm{IC}_{50} \\
(\mu \mathrm{g} / \mathrm{mL})\end{array}$} \\
\hline & 100 & 50 & 25 & 12.5 & 6.3 & \\
\hline $80 \% \mathrm{MeOH}$ ext. & $66.3 \pm 2.1^{\mathrm{d} 1)}$ & $49.7 \pm 1.3^{c}$ & $35.3 \pm 2.1^{\mathrm{c}}$ & $18.8 \pm 2.1^{\mathrm{bc}}$ & $9.8 \pm 1.3^{b}$ & $50.9 \pm 1.9$ \\
\hline$n$-Hexane layer & $48.4 \pm 1.4^{\mathrm{e}}$ & $31.9 \pm 1.1^{\mathrm{d}}$ & $13.9 \pm 0.1^{\mathrm{d}}$ & $7.6 \pm 0.2^{\mathrm{cd}}$ & $1.5 \pm 0.1^{\mathrm{c}}$ & $>200$ \\
\hline EtOAc layer & $89.2 \pm 1.8^{\mathrm{b}}$ & $72.8 \pm 3.1^{b}$ & $43.6 \pm 1.3^{b}$ & $24.7 \pm 0.3^{\mathrm{b}}$ & $10.0 \pm 0.8^{\mathrm{b}}$ & $27.8 \pm 0.9$ \\
\hline$n$-BuOH layer & $40.1 \pm 1.3^{\mathrm{f}}$ & $23.7 \pm 1.1^{\mathrm{d}}$ & $12.6 \pm 1.0^{\mathrm{d}}$ & $3.4 \pm 1.2^{\mathrm{d}}$ & $0.9 \pm 1.4^{\mathrm{c}}$ & $>200$ \\
\hline $\mathrm{H}_{2} \mathrm{O}$ layer & $72.6 \pm 2.1^{\mathrm{c}}$ & $51.6 \pm 2.3^{\mathrm{c}}$ & $37.8 \pm 0.5^{\mathrm{c}}$ & $15.2 \pm 1.4^{\mathrm{b}}$ & $7.1 \pm 1.1^{\mathrm{b}}$ & $45.2 \pm 3.0$ \\
\hline$(+)$-Catechin ${ }^{2)}$ & $99.7 \pm 0.1^{\mathrm{a}}$ & $97.5 \pm 0.1^{\mathrm{a}}$ & $85.2 \pm 1.2^{\mathrm{a}}$ & $39.3 \pm 1.1^{\mathrm{a}}$ & $32.7 \pm 0.7^{\mathrm{a}}$ & $14.6 \pm 0.4$ \\
\hline
\end{tabular}

${ }^{1)}$ Scavenging activities are expressed as the mean $\pm \mathrm{SD}$ of triplicate experiments. Mean separation within columns of respective seasons by Duncan's multiple range test at $\mathrm{p}=0.05$. ${ }^{2)}(+)$-Catechin was used as a positive control.

Table 4. Inhibitory effects of the $80 \%$ methanolic extract of Mongolian I. bungei and its $n$-hexane-, EtOAc-, $n$ - $\mathrm{BuOH}$-, and $\mathrm{H}_{2} \mathrm{O}$-soluble portions against a-glucosidase

\begin{tabular}{|c|c|c|c|c|c|c|}
\hline \multirow{2}{*}{ Samples } & \multicolumn{5}{|c|}{ Inhibition (\%) } & \multirow{2}{*}{$\begin{array}{c}\mathrm{IC}_{50} \\
(\mu \mathrm{g} / \mathrm{mL})\end{array}$} \\
\hline & 50 & 25 & 12.5 & 6.3 & 3.1 & \\
\hline $80 \% \mathrm{MeOH}$ ext. & $90.9 \pm 1.7^{\mathrm{d} 1)}$ & $55.8 \pm 1.4^{\mathrm{d}}$ & $22.0 \pm 1.1^{\mathrm{d}}$ & $11.0 \pm 1.2^{\mathrm{d}}$ & $4.9 \pm 0.3^{\mathrm{d}}$ & $21.7 \pm 1.3$ \\
\hline$n$-Hexane layer & $97.0 \pm 1.0^{\mathrm{b}}$ & $82.8 \pm 2.4^{\mathrm{c}}$ & $38.9 \pm 2.1^{\mathrm{c}}$ & $13.6 \pm 2.1^{\mathrm{c}}$ & $6.9 \pm 0.5^{\mathrm{c}}$ & $14.3 \pm 0.6$ \\
\hline EtOAc layer & $99.4 \pm 2.1^{\mathrm{a}}$ & $96.6 \pm 1.4^{\mathrm{a}}$ & $85.3 \pm 4.2^{\mathrm{a}}$ & $64.5 \pm 1.5^{\mathrm{a}}$ & $32.0 \pm 1.2^{\mathrm{a}}$ & $4.6 \pm 0.1$ \\
\hline n-BuOH layer & $11.4 \pm 1.5^{\mathrm{f}}$ & $9.4 \pm 0.9^{\mathrm{e}}$ & $8.5 \pm 1.4^{\mathrm{e}}$ & $6.7 \pm 0.5^{\mathrm{e}}$ & $3.5 \pm 1.5^{\mathrm{e}}$ & $>200$ \\
\hline $\mathrm{H}_{2} \mathrm{O}$ layer & $92.4 \pm 2.5^{\mathrm{c}}$ & $85.9 \pm 1.2^{\mathrm{b}}$ & $74.8 \pm 2.0^{\mathrm{b}}$ & $44.4 \pm 0.6^{b}$ & $27.0 \pm 2.1^{\mathrm{b}}$ & $6.7 \pm 0.4$ \\
\hline Acarbose $^{2)}$ & $14.1 \pm 0.9^{\mathrm{e}}$ & $9.3 \pm 1.9^{\mathrm{e}}$ & $2.6 \pm 0.5^{\mathrm{f}}$ & $2.1 \pm 0.4^{\mathrm{f}}$ & $1.1 \pm 0.4^{\mathrm{f}}$ & $473.2 \pm 5.5$ \\
\hline
\end{tabular}

${ }^{1)}$ Scavenging activities are expressed as the mean $\pm \mathrm{SD}$ of triplicate experiments. Mean separation within columns of respective seasons by Duncan's multiple range test at $\mathrm{p}=0.05$.

${ }^{2)}$ Acarbose was used as a positive control. 
평가한 결과, Table 4에서 나타낸 것처럼 $80 \% \mathrm{MeOH}$ 추출 물의 $\mathrm{IC}_{50}$ 값이 $21.7 \pm 1.3 \mu \mathrm{g} / \mathrm{mL}$ 의 매우 우수한 효소 저해활 성을 나타내었고, 총 페놀함량이 가장 높은 EtOAc 가용분 획물의 $\mathrm{IC}_{50}$ 값이 $4.6 \pm 0.1 \mathrm{\mu g} / \mathrm{mL}$ 로, 양성 대조군인 acarbose $\left(\mathrm{IC}_{50}\right.$ 값 $\left.=473.2 \pm 5.5 \mu \mathrm{g} / \mathrm{mL}\right)$ 보다 100 배 이상의 우수한 a -glucosidase 저해활성을 확인하였다. 다음으로 $\mathrm{H}_{2} \mathrm{O}$ 및 $n$-hexane 가용 분획물에서 각 $\mathrm{IC}_{50}$ 값 $6.7 \pm 0.4 \mathrm{\mu g} / \mathrm{mL}, 14.3 \pm$ $0.6 \mathrm{\mu g} / \mathrm{mL}$ 의 저해활성을 나타났으며, $n-\mathrm{BuOH}$ 가용 분획물 에서는 $>200 \mu \mathrm{gg} / \mathrm{mL}$ 로 상대적으로 낮은 a-glucosidase 저해 활성을 확인하였다. 이전의 연구로 부터 몽골 약용 식물인 Ferula mongolica의 뿌리 추출물에서 우수한 a-glucosidase 저해활성을 나타내는 활성 성분이 분리 및 동정되었으며 (17), 본 연구에서 얻어진 결과인 우수한 a-glucosidase 저해 활성을 가진 몽골산 I. bungei의 EtOAc 가용 분획물로 부터 활성물질의 분리 및 구조결정을 통해 활성 및 활성기작 평가가 필요하다고 사료된다.

\section{요 약}

몽골산 I. bungei를 $80 \%$ 메탄올로 침지 추출하여 얻어진 추출물에 대해 $n$-hexane, EtOAc 및 $n$ - $\mathrm{BuOH}$ 의 유기용매를 활용하여 순차 분획을 실시하였고, 얻어진 결과물에 대하 여 총 페놀함량, $\mathrm{DPPH}, \mathrm{ABTS}^{+}$라디칼 소거능 및 $\mathrm{a}$ -glucosidase 저해활성을 평가하였다. DPPH 라디칼 소거활 성은 페놀성 화합물의 함량이 높은 EtOAc 가용 분획물에서 $\mathrm{IC}_{50}$ 값이 $148.7 \pm 11.6 \mu \mathrm{g} / \mathrm{mL}$ 으로 우수한 $\mathrm{DPPH}$ 라디칼 소거 활성을 확인하였고, $\mathrm{ABTS}^{+}$라디칼 소거활성 역시 I. bungei 의 $\mathrm{EtOAc}$ 가용 분획물에서 $\mathrm{IC}_{50}$ 값이 $27.8 \pm 0.9 \mu \mathrm{g} / \mathrm{mL}$ 의 매우 우수한 라디칼 소거활성을 확인하였고, 다량 존재하 는 페놀성 화합물과 라디칼 소거활성의 관련성을 나타내었 다. 또한 a-glucosidase 저해활성을 평가한 결과 EtOAc 가용 분획물에서 $\mathrm{IC}_{50}$ 값은 $4.6 \pm 0.1 \mathrm{\mu g} / \mathrm{mL}$ 의 강력한 저해활성을 나타내었으며, 이는 양성 대조군인 acarbose의 $\mathrm{IC}_{50}$ 값인 $473.2 \pm 5.5 \mathrm{\mu g} / \mathrm{mL}$ 과 비교했을 때 매우 우수한 활성을 나타내 었으며, 다양한 화합물이 함유된 상태의 추출물 시료를 단 일물질로 정제할 경우 더욱 우수한 활성의 화합물이 존재할 가능성을 기대하게 한다. 향후 이들 추출물의 활성물질 동 정을 통한 활성 기작에 대한 연구가 필요하며, 본 연구결과 로 보다 우수한 라디칼 소거활성 및 a-glucosidase 저해활성 을 가지는 새로운 천연 기능성 소재 발굴을 위한 기초자료 로 활용 가능할 것으로 사료된다.

\section{References}

1. Fang YZ, Yang S, Wu G (2002) Free radicals, antioxidants, and nutrition. Nutrition, 18, 872-879

2. Videla LA, Fermandez V (1988) Biochemical aspects of cellular oxidative stress. Arch Biol Med Exp, 21, 85-92

3. Halliwell B, Aruoma OI (1991) DNA damage by oxygen-derived species its mechanism and measurement in mammalian systems. FEBS Lett, 281, 9-19

4. Jennings PE, Barnett AH (1988) New approaches to the pathogenesis and treatment of diabetic microangiopathy. Diabetic Med, 5, 111-117

5. Shim JS, Kim SD, Kim TS, Kim KN (2005) Biological activities of flavonoid glycosides isolated from Angelica keiskei. Korean J Food Sci Technol, 37, 78-83

6. Farag RS, Badei AZMA, Hewedi FM, EI-Baroty GSA (1989) Antioxidant activity of some spice essential oils on linoleic acid oxidation in aqueous media. J Am Oil Chem Soc, 66, 792-799

7. Frei B (1994) National Antioxidants in Human Health and Disease. Academic Press, San Diego, CA, USA, p 44-55

8. Branen AL (1975) Toxicology and biochemistry of butylated hydroxyanisole and butylated hydroxytoluene. J Am Oil Chem Soc, 52, 59-63

9. Rubin RR, Peyrot M (1999) Quality of life and diabetes. Diabetes Metab Res Rev, 15, 205-218

10. Patel DK, Kumar R, Laloo D, Hemalatha S (2012) Diabetes mellitus: An overview on its pharmacological aspects and reported medicinal plants having antidiabetic activity. Asian Pac J Trop Biomed, 2, 411-420

11. Lee EB, Na GH, Ryu CR, Cho MR (2004) The review on the study of diabetes mellitus in oriental medicine journals. J Korean Orient Med, 25, 169-179

12. Schwarz K, Mertz W (1959) Chromium (III) and the glucose tolerance factor. Arch Biochem Biophys, 85, 292-295

13. Derosa G, Maffioli P (2012) a-Glucosidase inhibitors and their use in clinical practice. Arch Med Sci, 8, 899-906

14. Tsujimoto T, Shioyama E, Moriya K, Kawaratani H, Shirai Y, Toyohara M, Mitoro A, Yamao J, Fujii H, Fukui H (2008) Pneumatosis cystoides intestinalis following alpha-glucosidase inhibitor treatment: A case report and review of the literature. World J Gastroenterol, 14, 6087-6092

15. Kihara Y, Ogami Y, Tabaru A, Unoki H, Otsuki M (1997) Safe and effective treatment of diabetes mellitus associated with chronic liver diseases with an alpha-glucosidase inhibitor, acarbose. J Gastroenterol, 32, 777-782 
16. Zhang A, Ye F, Lu J, Zhao S (2013) Screening a -glucosidase inhibitor from natural products by capillary electrophoresis with immobilised enzyme onto polymer monolith modified by gold nanoparticles. Food Chem, 141, 1854-1859

17. Choudhary MI, Baig I, Nur-e-Alam M, Shahzad-ul-Hussan $\mathrm{S}$, Ondognii P, Bunderya M, Oyun Z, Atta-ur-Rahman (2001) New a-glucosidase inhibitors from the Mongolian medicinal plant Ferula mongolica. Helv Chim Acta, 84, 2409-2416

18. Atta-ur-Rahman M, Choudhary MI, Nur-e-Alam M, Ndognii PO, Badarchiin T, Purevsuren G (2000) Two new quinones from Iris bungei. Chem Pharm Bull, 48, 738-739

19. Lin B, Wang G, Wang Q, Ge C, Qin M (2011) A new belamcandaquinone from the seeds of Iris bungei Maxim.. Fitoterapia, 82, 1137-1139

20. Choudhary MI, NureAlam M, Akhtar F, Ahmad S, Baig I, Ondoegnii P, Gombosurengyin P, AttaurRahman (2001) Five new peltogynoids from underground parts of Iris bungei: A Mongolian medicinal plant. Chem Pharm Bull, 49, 1295-1298

21. Choudhary MI, Nur-e-Alam M, Baig I, Akhtar F, Khan AM, Ndognii PO, Badarchiin T, Purevsuren G, Nahar N, Atta-ur-Rahman (2001) Four new flavones and a new isoflavone from Iris bungei. J Nat Prod, 64, 857-860

22. Gao X, Bjork L, Trajkovski V, Uggla M (2000) Evaluation of antioxidant activities of rosehip ethanol extracts in different test systems. J Sci Food Agric, 80, 2021-2027
23. Blois MS (1958) Antioxidant determinations by the use of a stable free radical. Nature, 181, 1199-1200

24. Re R, Pellegrini N, Proteggente A, Pannala A, Yang M, Rice-Evans C (1999) Antioxidant activity applying an improved ABTS radical cation decolorization assay. Free Radical Biol Med, 26, 1231-1237

25. Eom SH, Lee SH, Yoon NY, Jung WK, Jeon YJ, Kim SK, Lee MS, Kim YM (2012) a-Glucosidase- and a -amylase inhibitory activities of phlorotannins from Eisenia bicyclis. J Sci Food Agric, 92, 2084-2090

26. Wang SY, Chang HN, Lin KT, Lo CP, Yang NS, Shyur LF (2003) Antioxidant properties and phytochemical characteristics of extracts from Lactuca indica. J Agric Food Chem, 51, 1506-1512

27. Selenge E, Murata T, Tanaka S, Sasaki K, Batkhuu J, Yoshizaki F (2014) Monoterpene glycosides, phenylpropanoids, and acacetin glycosides from Dracocephalum foetidum. Phytochemistry, 101, 91-100

28. Boldbaatar D, EI-Seedi HR, Findakly M, Jabri S, Javzan B, Choidash B, Goransson U, Hellman B (2014) Antigenotoxic and antioxidant effects of the Mongolian medicinal plant Leptopyrum fumarioides (L): An in vitro study. J Ethnopharmacol, 155, 599-606

29. Birasuren B, Kim NY, Jeon HL, Kim MR (2013) Evaluation of the antioxidant capacity and phenolic content of Agriophyllum pungens seed extracts from Mongolia. Prev Nutr Food Sci, 18, 188-195 